\title{
THE CONSTITUTIONAL CONTROL SYSTEM IN PORTUGAL: PRECONDITIONS OF FORMING AND FEATURES OF FUNCTIONING
}

\author{
Vladimir V. Slezhenkov \\ Volgograd State University, Volgograd, Russian Federation \\ Andrey E. Lakeev \\ Volgograd State Medical University, Volgograd, Russian Federation
}

\begin{abstract}
Introduction: the scientific interest in the study of the specifics of the Portuguese constitutional control system is predetermined by insufficient knowledge of the relevant issues in the Russian legal doctrine, the uniqueness of the historical prerequisites for the formation of this system and its subsequent development, the importance of the role in the context of the transition from authoritarianism to democracy. Methods: the methodological framework for the study is a set of methods of scientific knowledge, among which the main are the methods of historicism, systematic analysis and comparative law. Results: the study identified the ideological and historical factors that had influenced the formation of the considered constitutional control system, conducted its comparison with the foreign practices, analyzed the basics of its regulatory framework, and determined the features of its functioning. The research substantiates the conclusions about the Portuguese constitutional court's having exclusively broad powers, about the democracy of the considered system, the combination of signs of decentralization and centrality in it with the priority of the latter, the special nature of the considered system, which is significantly different from the foreign analogues.
\end{abstract}

Key words: constitutional control, constitutional justice, constitutional court, Portugal, comparative constitutional law.

Citation. Slezhenkov V.V., Lakeev A.E. The Constitutional Control System in Portugal: Preconditions of Forming and Features of Functioning. Legal Concept, 2019, vol. 18, no. 1, pp. 157-161. (in Russian). DOI: https://doi.org/ 10.15688/lc.jvolsu.2019.1.22

\section{СИСТЕМА КОНСТИТУЦИОННОГО КОНТРОЛЯ В ПОРТУГАЛИИ: ПРЕДПОСЫЛКИ ФОРМИРОВАНИЯ И ОСОБЕННОСТИ ФУНКЦИОНИРОВАНИЯ}

\author{
Владимир Владимирович Слеженков \\ Волгоградский государственный университет, г. Волгоград, Российская Федерация
}

Андрей Евгеньевич Лакеев

Волгоградский государственный медицинский университет, г. Волгоград, Российская Федерация

Введение: научный интерес к исследованию специфики португальской системы конституционного контроля предопределен малой изученностью соответствующих вопросов в российской правовой доктрине, своеобразием исторических предпосылок формирования данной системы и ее последующего развития, важностью ее роли в контексте перехода от авторитаризма к демократии. Методы: методологическую основу исследования составляет совокупность методов научного познания, среди которых основное место зани- 


\section{МЕЖДУНАРОДНОЕ ПРАВО И СРАВНИТЕЛЬНОЕ ПРАВОВЕДЕНИЕ}

мают методы историзма, системности, анализа и сравнительно-правовой. Результаты: в исследовании выявлены идейно-исторические факторы, повлиявшие на становление рассмотренной системы конституционного контроля, проведено ее сопоставление с зарубежными практиками, рассмотрены основы ее нормативного регулирования, определены особенности ее функционирования. В статье обосновываются выводы о наличии у конституционного суда Португалии исключительно широких полномочий, демократичности рассмотренной системы, сочетания в ней признаков децентрализованности и централизованности при приоритете последних, особом характере рассмотренной системы, существенно отличающемся от зарубежных аналогов.

Ключевые слова: конституционный контроль, конституционное правосудие, конституционный суд, Португалия, сравнительное конституционное право.

Цитирование. Слеженков В. В., Лакеев А. Е. Система конституционного контроля в Португалии: предпосылки формирования и особенности функционирования // Legal Concept = Правовая парадигма. - 2019. T. 18, № 1. -C. 157-161. - DOI: https://doi.org/10.15688/lc.jvolsu.2019.1.22

\section{Введение}

Исследования особенностей современного конституционного строя Португалии находятся - в сравнении с изучением соответствующих институтов ряда других европейских государств - на периферии внимания в российской правовой доктрине. В этой связи, а также вследствие своеобразия исторических предпосылок формирования и современного характера модели конституционного контроля, значительной роли последнего в контексте коренного реформирования политико-правовой системы и демократизации политического режима в стране, анализ нормативных основ и практики функционирования португальского Конституционного суда (Tribunal Constitucional) представляет значительный сравнительно-правовой интерес.

\section{Исторические предпосылки формирования системы конституционного контроля в Португалии}

В сравнительно-историческом аспекте примечательно, что именно Конституция Португалии 1911 г. впервые в мировой практике закрепила принцип судебного контроля конституционности. Но реалии последующего развития страны (социально-политический кризис, военные перевороты, утверждение диктаторского режима «Нового государства» Салазара - Каэтану) предопределили отсутствие практических инициатив по введению судебного конституционного контроля.

Специализированная система конституционного контроля была создана только Кон- ституцией 1976 г. [4], принятой на основе компромисса основных политических сил, поляризованных после революции 1974 года. Это обстоятельство, как и отсутствие демократической традиции в истории страны, предопределило влияние на содержание ее Основного закона конституционного опыта как западноевропейских государств, переживших в 40-е - 70-е гг. XX в. переход к демократии (ФРГ, Италия, Испания), так и социалистических стран. Последующие ревизии конституционного текста придали ему политически умеренный характер, что не в последнюю очередь было связано с ускоренной интеграцией Португалии в европейские структуры. Изменения претерпела и система конституционного контроля - вначале квазисудебная (представленная Революционным Советом, далее - конституционной комиссией), а с 1982 г. - судебная; тогда же был принят органический закон «О Конституционном суде» [6].

\section{Основные особенности португальской модели конституционного контроля}

Модель португальского конституционного контроля изначально выстроена по типу централизованной, характерной для перечисленных западноевропейских государств, что было опосредовано отсутствием достаточных гарантий и свободы в формировании позиций у существовавших судов [5]. Впоследствии был введен ряд черт децентрализованного контроля: общие суды также могут отказаться применять закон, который считают неконституционным, но их решение имеет значение только для конкретного 
дела и может обжаловаться в Конституционный суд. Но если суды трижды констатировали неконституционность закона, представители Генеральной прокуратуры при Конституционном суде или сами судьи могут обратиться с требованием принятия общеобязательного решения об отмене такого закона. При этом исключено производство по предварительным запросам судов, но есть возможность направления запроса о конституционности по ходатайству стороны процесса в общем суде [1, с. 89].

Среди полномочий Конституционного суда Португалии, наряду с широкими «классическими» (проверка не только конституционности, но и законности (формальной и материальной) законов, нератифицированных международных договоров (нормы ратифицированных договоров могут быть признаны не подлежащими применению при констатации нарушений фундаментальных конституционных положений); предварительное утверждение конституционности референдумов), стоит отметить осуществление контроля за имущественным положением чиновников, соответствием Конституции и законностью уставов политических партий, регистрация и проверка банковских счетов последних.

Применительно к принципам деятельности Конституционного суда интересно упомянуть, что Конституция Португалии предусматривает обязательность толкования конституционных и законодательных норм с позиций соответствия Всеобщей декларации прав человека [2]; Конституции присуще декларирование многих прав человека «новых поколений», не предусмотренных ранее принятыми международно-правовыми актами, в том числе Европейской конвенцией о защите прав человека и основных свобод [3]. В доктрине и судебной практике Португалии признано, что основные права должны толковаться в соответствии с различными международными механизмами по правам человека, с обязательной оценкой «превосходства норм», устанавливающих высший уровень защиты основных прав.

\section{Специфика функционирования Конституционного суда в Португалии}

Процедура конституционного судопроизводства в Португалии отличается рядом осо- бенностей. Так, судопроизводство осуществляется не публично, по письменной процедуре (что характерно для децентрализованного (Дания) или квазисудебного (Франция) контроля); стороны представляются адвокатами (что не всегда присуще системам контроля, предполагающим устность и состязательность (Россия, Армения, Грузия)). Исключение составляет публичное рассмотрение дел о признании осуществления организацией фашистской идеологии (эта оговорка отражает исторические особенности принятия Конституции). Есть и формальное исключение - вызов заявителя для уточнения его позиции. Возможно принятие решения на основании отличающихся от заявленных конституционных положений (как и в России), однако в случае конкретного нормоконтроля Конституционный суд ограничен толкованием обратившегося суда относительно спорного положения. По общему правилу, для обращения в Конституционный суд необходимо исчерпание внутригосударственных средств судебной защиты.

Действие решения Конституционного суда распространяется на конкретное дело, но если суд трижды примет решения по одному и тому же вопросу, он может начать абстрактный контроль оспариваемого нормативного акта и лишить его юридической силы. Такой исход, однако, не предопределен - суд вправе принять и новое решение, пересмотрев в пленарном заседании ранее сформулированные позиции своих палат. Например, конституционность ранее оспоренных положений закона была констатирована в решении № 221/2009 от 5 мая 2009 г. [8] по делу, в рамках которого представитель Генеральной прокуратуры просил признать неконституционной норму Исполнительного закона «Об установлении платежей за оказание медицинской помощи в учреждениях или службах Национальной Службы Здравоохранения».

Наконец, стоит указать, что решения португальского Конституционного суда подчиняются принципу ex tunc. Но, в отличие, например, от российской практики, действие данного принципа ограничивается признанием последующей недействительности актов, за исключением окончательных решений су- 


\section{МЕЖДУНАРОДНОЕ ПРАВО И СРАВНИТЕЛЬНОЕ ПРАВОВЕДЕНИЕ}

дов. Обратная сила решений Конституционного суда имеет место, когда признанная неконституционной норма касается уголовных, дисциплинарных, административных дел и является менее благоприятной для обвиняемого (правонарушителя). Так, решением суда № 232/2004 от 31.03.2004 признана неконституционность нормы относительно дополнительных наказаний, касающихся высылки иностранных граждан, несущих ответственность за несовершеннолетних граждан Португалии и проживающих на ее территории [7]. Действие этой нормы распространено на дела, в которых приговоры уже опубликованы, но не исполнены на дату опубликования решения.

\section{Выводы}

Конституционный контроль в Португалии является «смешанным» при преобладании характеристик централизованных систем; Конституционный суд обладает исключительно широкими полномочиями, ряд из которых не присущ аналогичным органам в иных государствах. В сравнительно-правовом аспекте особый интерес представляют такие черты рассматриваемого института, как обязательность профессионального представительства заявителей в Конституционном суде, ориентированность на учет положений, устанавливающих наивысший уровень гарантий прав человека (а не только на «иерархию норм»), возможность формулирования общеправовых принципов, прямо не предусмотренных в законодательстве. Все это позволяет подчеркнуть высокую степень демократичности конституционного судопроизводства в Португалии, несмотря на наличие у него и таких особенностей, как непубличность и письменный характер, присущих, как правило, квазисудебным системам. Наконец, следует отметить, что своеобразие португальского конституционного контроля в значительной мере предопределено спецификой идейноисторических предпосылок ее создания, влиянием зарубежного опыта перехода от авторитаризма к демократии; тем не менее рассмотренная система отличается рядом особенностей, сочетание которых не наблюдается более в мировой практике.

\section{СПИСОК ЛИТЕРАТУРЫ}

1. Алмейда, Луиш Нунеш де. Развитие идеи демократического правового государства и применение вытекающих из нее принципов Конституционным Судом Португалии / Луиш Нунеш де Алмейда // Сравнительное конституционное обозрение. - 2004. - № 3. - С. 88-91.

2. Всеобщая Декларация прав человека : (принята Генеральной Ассамблеей ООН 10.12.1948). - Доступ из справ.-правовой системы «КонсультантПлюс».

3. Европейская Конвенция о защите прав человека и основных свобод : (Заключена в г. Риме 04.11.1950) - Доступ из справ.-правовой системы «КонсультантПлюс».

4. Конституция Португальской Республики от 2 апреля 1976 г. - Электрон. текстовые дан. Режим доступа: http://www.concourt.am/ armenian/legal_resources/world_constitutions/ constit/portugal/portug-r.htm. - Загл. с экрана.

5. Garlicki, L. Constitutional Courts Versus Supreme Courts / L. Garlicki // International Journal of Constitutional Law. - 2007. - № 5 (1). - Electronic text data. - Mode of access: https://academic.oup.com/icon/ article/5/1/44/722508\#FN59\#FN59. - Title from screen.

6. Lei Orgânica do Tribunal Constitucional // Lei n€ 28/82, de 15 de Novembro. - Electronic text data. - Mode of access: http://www.pgdlisboa.pt/leis/ lei_mostra_articulado.php?nid=423\&tabela=leis. Title from screen.

7. Ruling No. 232/2004, 31 of March of 2004.Electronic text data. - Mode of access: http:// www.tribunalconstitucional.pt/tc/en/acordaos/ 20040232s.html.

8. Ruling No. 221/2009, 5 of May of 2009. Electronic text data. - Mode of access: http:// www.tribunalconstitucional.pt/tc/en/acordaos/ 20090221s.html. - Title from screen.

\section{REFERENCES}

1. Almeyda L. Nunesh de. Razvitie idei demokraticheskogo pravovogo gosudarstva i primenenie vytekayushchikh iz nee printsipov Konstitutsionnym Sudom Portugalii [The Development of the Idea of a Democratic Rule of Law and the Application of the Principles Arising from it by the Constitutional Court of Portugal]. Sravnitelnoe konstitutsionnoe obozrenie, 2004, no 3. pp. 88-91.

2. Vseobshchaya Deklaratsiya prav cheloveka (prinyata Generalnoy Assambleey OON 10.12.1948). Access from Reference Legal Sistem 'Consultant Plus'.

3. Evropeyskaya Konventsiya o zashchite prav cheloveka i osnovnykh svobod (Zaklyuchena $v$ 
g. Rime 04.11.1950). Access from Reference Legal Sistem 'Consultant Plus'.

4. Konstitutsiya Portugalskoy Respubliki ot 2 aprelya $1976 \mathrm{~g}$. URL: http://www.concourt.am/ armenian/legal_resources/world_constitutions/ constit/portugal/portug-r.htm.

5. Garlicki L. Constitutional Courts Versus Supreme Courts. International Journal of Constitutional Law, 2007, no. 5 (1). URL: https://academic.oup.com/icon/ article/5/1/44/722508\#FN59\#FN59.
6. Lei Orgânica do Tribunal Constitucional. Lei ne 28/82, de 15 de Novembro. URL: http:// www.pgdlisboa.pt/leis/lei_mostra_articulado. php?nid=423\&tabela=leis.

7. Ruling No. 232/2004, 31 of March of 2004. URL: http://www.tribunalconstitucional.pt/tc/en/ acordaos/20040232s.html.

8. Ruling No. 221/2009, 5 of May of 2009. URL: http://www.tribunalconstitucional.pt/tc/en/acordaos/ 20090221s.html.

\section{Information about the Authors}

Vladimir V. Slezhenkov, Candidate of Sciences (Jurisprudence), Associate Professor, Department of Constitutional and Municipal Law, Volgograd State University, Prosp. Universitetsky, 100, 400062 Volgograd, Russian Federation, slezhenkov@yandex.ru, https://orcid.org/0000-0002-2863-6014

Andrey E. Lakeev, Candidate of Sciences (Jurisprudence), Associate Professor, Department of Philosophy, Bioethics and Law with the Course of Sociology of Medicine, Volgograd State Medical University, Pavshikh Bortsov Sq., 1, 400131 Volgograd, Russian Federation, and.lackeev@yandex.ru, https://orcid.org/0000-0003-3851-2207

\section{Информация об авторах}

Владимир Владимирович Слеженков, кандидат юридических наук, доцент кафедры конституционного и муниципального права, Волгоградский государственный университет, просп. Университетский, 100, 400062 г. Волгоград, Российская Федерация, slezhenkov@yandex.ru, https://orcid.org/0000-0002-2863-6014

Андрей Евгеньевич Лакеев, кандидат юридических наук, доцент кафедры философии, биоэтики и права с курсом социологии медицины, Волгоградский государственный медицинский университет, площадь Павших Борцов, 1, 400131 г. Волгоград, Российская Федерация, and.lackeev@yandex.ru,https://orcid.org/0000-0003-3851-2207 